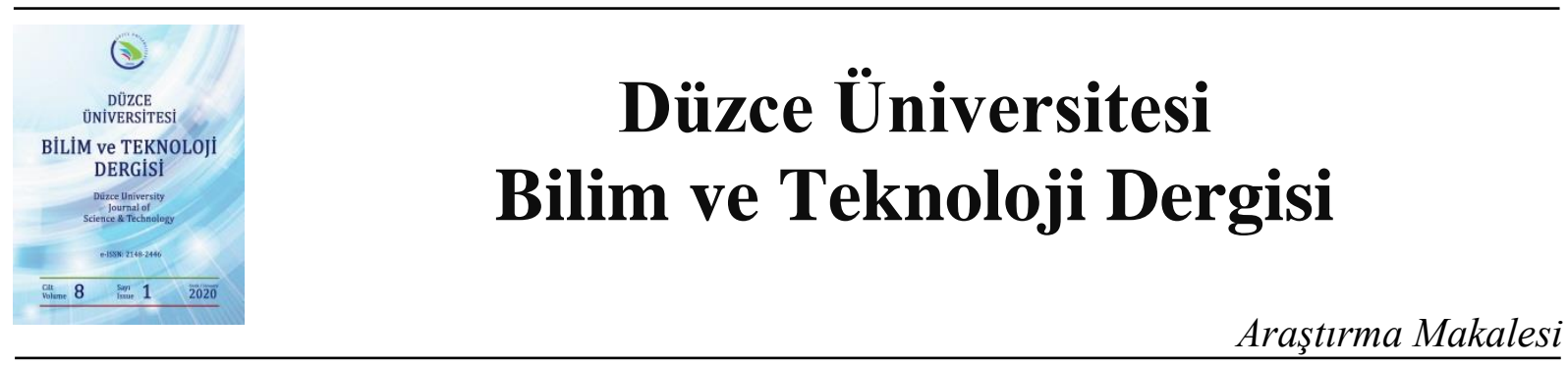

\section{Cep Telefonu Kullanıcılarının GSM Operatörü Tercihine Etki Eden Faktörlerin Araştırılması: Kütahya İli Örneği}

\author{
(D) Hasan ŞAHIN ${ }^{\mathrm{a}, *}$, (D) Bayram TOPAL ${ }^{\mathrm{b}}$ \\ ${ }^{a}$ Endüstri Mühendisliği Bölümü, Mühendislik ve Doğa Bilimleri Fakültesi, Bandırma Onyedi Eylül Üniversitesi, \\ Ballkesir, TÜRKIYE \\ ${ }^{b}$ Işsletme Bölümü, İsletme Fakültesi,Sakarya Üniversitesi, Sakarya, TÜRKIYE \\ * Sorumlu yazarin e-posta adresi: hsahin@ bandirma.edu.tr
}

DOI: 10.29130/dubited.646686

\begin{abstract}
ÖZET
Teknolojinin hızla gelişimi ve küreselleşen pazar koşulları rekabetin daha da artması ile işletmeler yeni pazarlama stratejileri geliştirerek müşteriyi merkezli bir anlayışla müşteri memnuniyetini en üst düzeye çıkararak müşteri sadakati oluşturmayı amaçlamaktadır. Günümüzde teknoloji; özel olarak bilişim teknolojileri hızı bir şekilde gelişmekte ve bunun bir doğal sonucu olarak hayatı daha fazla etkisi altına almaktadır. Özellikle taşınabilir cihazlar; başta cep ve akıllı cep telefonu olmak üzere dizüstü bilgisayarlar, tablet PC'ler, gibi mobil cihazlar, yaşamımızın vazgeçilmez bir parçası olmaya başlamıştır. Mobil cihazların yaygınlaşması Dünyada olduğu gibi Türkiye'de de GSM sektörünün hızla gelişmesine yol açmıştır. Türkiye'de GSM sektöründe faaliyet gösteren üç operatör bulunmaktadır. Türkiye'de 2008 yılı başında 62,9 milyon olan mobil telefon abone sayısı, 2018 yılı eylül ayında 80,6 milyona ulaşmıştır. Böylece 10 yıl içerisinde abone sayısında \%28'lik bir artış kaydedilmiştir. 2018 Eylül ayı itibarıyla GSM operatörlerinin abone yüzdeleri Turkcell için \%43,3, Vodafone için 30,9 ve TT Mobil için \%25,8 olarak gerçekleşmiştir. Bu çalışmanın amacı Kütahya ilinde cep telefonu kullanıcılarının GSM operatörü tercihine etki eden faktörlerin belirlenmesidir. Bu amaçla 260 cep telefonu kullanıcısına anket uygulanmış ve hizmet kalitesi, fiyat, reklam, kapsama alanı, akraba ve yakın çevre faktörleri gibi faktörlerin GSM operatörü tercihindeki etkileri araştırılmıştır. Ankete katılanların \%44,2'si kadın, \%55,8'i erkek olup, üç mobil işletmesi içinde Türk Telekom \%26,9, Turkcell \%33,8 ve Vodafone $\% 39,2$ seviyesinden katılım sağlanmıştır. Anket çalışmasının iç tutarlılı̆ı̆ için Cronbach alfa katsayısı 0,957 olarak bulunmuş olup güvenilirliğinin oldukça yüksek olduğu saptanmıştır.
\end{abstract}

Anahtar Kelimeler: GSM, Hizmet Kalitesi, Müşteri Memnuniyeti.

\section{Investigation of the Factors Affecting the Choice of Mobile Operator in the Mobile Phone Users: The Case of Kutahya}

\begin{abstract}
$\underline{\text { ABSTRACT }}$
Rapid development of technology and the globalized market conditions further increase the competitiveness of businesses aims to build customer loyalty by removing the highest level of customer satisfaction based on an understanding of the customer by developing new marketing strategies. Nowadays technology; in particular,
\end{abstract}


information technologies are developing rapidly and have a greater impact on life as a natural consequence of it. Especially portable devices; mobile devices such as laptops, tablet PCs, especially mobile and smart phones have become an indispensable part of our lives. The spread of mobile devices in Turkey as well as in the world has led to the rapid development of the GSM sector. There are three GSM operators in Turkey operating in the sector. Number of mobile phone subscribers in Turkey with 62.9 million at the beginning of 2008, in September 2018 reached 80.6 million. Thus, the number of subscribers increased by $28 \%$ in 10 years. As of September 2018, subscriber percentage of GSM operators was $43.3 \%$ for Turkcell, 30.9\% for Vodafone and 25.8\% for TT Mobil. The aim of this study is to determine the factors affecting the mobile phone users' preference of GSM operators in Kutahya province. For this purpose, 260 mobile phone users were surveyed and the effects of factors such as service quality, price, advertisement, coverage, relatives and near environment factors on GSM operator preference were investigated. $44.2 \%$ of the respondents were women, $55.8 \%$ were male, $26.9 \%$ of Turk Telekom in three mobile company Turkcell and Vodafone $33.8 \%$ the level of participation was $39.2 \%$. The Cronbach alpha coefficient was found to be 0.957 for the internal consistency of the questionnaire and its reliability was found to be quite high.

Keywords: GSM, Service Quality, Customer Satisfaction.

\section{GIRIS}

Teknolojide yaşanan gelişmeler küresel ekonomik pazarda rekabetin her geçen gün artmasına neden olmaktadır. Bu nedenle ürünler arasındaki fark azalmakta, teknolojinin gelişme hızı ile ürün yaşam süresi kısalmakta, müşteri istek ve beklentileri de aynı şekilde artmaktadır. Bu gelişmeler geçmişte yeni müşteriler kazanarak pazar payını artıran işletmeleri mevcut müşterilerini korumaya yöneltmiştir [5]. Teknoloji, insanın "çıplak doğa" ya bir katkısı olarak tanımlanabilir. Bunun yanında fiziksel bir mekanda yer tutacak nesneler üretilmekte; eşya, eşyayı yapan makineler üretilmektedir. Bu sayede insanın içi genişlemekte, bedeni ise teknolojik araç gereçlerle donanmaktadır. Teknolojik araç ve gereçlerle erişilebilirlik artmakta; görülemez yerler görülmekte, gidilemez yerlere gidilmekte ve duyulamaz sesler işitilmektedir [17].

1980'li y1llardan sonra yaşanan teknolojik ve küresel değişimler birçok alanda gelişmelere neden olmuş bu durum da müşterilerin istek ve ihtiyaçlarının değişmesi ile ürün ve hizmetlerden beklentini arttırmıştır. Müşteri istek ve ihtiyaçlarında ki artış ve ekonomide yaşanan değişim ve gelişimlerle birlikte tüketicilere sunulan ürün ve hizmetler daha da modern hale gelmiştir. Günümüzde işletmeler artık müşteri odaklı pazarlama stratejileri ile sonsuz müşteri memnuniyetini ve müşteri sadakati sağlamayı hedef haline getirmişlerdir. Modern yaşamda şehirlerdeki nüfus oranında artış, insanların gelir ve yaşam düzeylerinde yükselme, geleneksel pazarlama anlaşıyışı da değişmiş, yeni yaklaşım ve anlayışlar meydana gelmiştir. Günümüzde artık işletmelerin ana hedefi; pazar paylarını ve kârlarını arttırırken bu sayede müşteri memnuniyetini sağlamak hatta müşterilerin ürün ve hizmetlerde beklentisinin üstüne çıkmaktır [8]. "Memnun olmak" tüketicilerin ürün ve hizmeti satın almadan önce ve satın aldıktan sonraki beklentinin karşılanması düzeyi şekilde tanımlanabilir. Bu şekilde işletmelerin kâr ve performans artması gibi birçok avantaj sağlanabilir. Başka bir deyişle müşteri memnuniyetinin artması müşterilerin işletmeye ve markaya olan bağlılıklarını, yeniden satın alma davranışlarını ve sadakatleri etkiler [1].

Cep telefonu pazarı ülke ekonomileri için oldukça önemli bir seviyeye ulaşmış olmakla beraber gelişimini hızla sürdürmektedir. 2017 yılında cep telefonu kullanıcı sayısının 5,135 milyar kişiye ulaşmıştır. Bunun yanı sıra Türkiye'de akıllı telefon kullanıcı sayısının 2017 yılında 41,06 milyon kişi, 2018 yılında ise 46,52 milyon kişi olacağı öngörülmektedir. Bu pazardaki hızlı değişimlere paralel 
olarak markaların pazar payları da sürekli değişmektedir. Özellikle Türkiye gibi gelişen teknolojiyi yakından takip eden tüketicilerin olduğu ekonomilerde, bu değişim ve gelişim çok daha hızlı olmaktadır. Türkiye pazarına 1999-2005 döneminde 50 milyonun üzerinde cep telefonu giriş yaparken; 2016 yılı için bu sayının 12,5 milyon olduğu ifade edilmektedir [5]. Bu pazarda sunulan yeni teknolojiler ile tüketici talebinin hız kesmeden devam etmesi, pazarın büyüme potansiyeli ve markaların pazar payı değişimleri dikkate alındığında; firmaların pazarlama ve satış politikaları açısından müşteri bağlılı̆g kavramı ön plana çıkmaktadır. Ayrıca cep telefonu pazarındaki tüketicilerin önemli bir kısmını Y kuşağı ya da dijital kuşak olarak adlandırılan kitlenin oluşturduğu düşünüldüğünde; müşteri bağlılığı ölçümünün yapılmasının ve firma politikalarında kullanılmasının ne kadar önemli olduğu anlaşılmaktadır [5].

Cep telefonları artık insanoğlunun yapmak istediği herhangi bir şeye ulaşabilmesini sağlayan vazgeçilmez bir araç haline gelmiştir. Cep telefonları hayatımızda hem gerçek hem de hayali günlük yaşantımızda olaylara tepki verme yeteneğimizde önemli gelişmelere neden olmakta ve insanoğluna sosyal bir nitelik kazandırmıştır. Kullanıcılarına bir yandan iş bulmasına yardımcı olurken diğer yandan da dinlemek istediği her müzik parçasını kolaylıkla kaydedebilme imkanı sağlamaktadır. Ayrıca hisse seneti takibi, fotoğraf paylaşmak, spor müsabakalarının sonuçlarını incelemek ve dünyanın her yerine metin, görüntü, video ve sesli mesaj göndermek oldukça kolay bir hale gelmiştir. Başarılı olabilmek için artık 7/24 erişilebilir olmak oldukça önemlidir. Ve bu mucizevi elektronik cihaz ile insanlar daha bağlantılı, daha verimli, daha eğlenceli ve kendini daha iyi hissetmesini sağlamaktadır [12].

\section{LITERATÜR TARAMASI}

Günümüzde akıllı telefonların öneminin artması son dönemlerde birçok çalışmanın da konusu olmuş ve bu konuda yapılan araştırma sayısı artmıştır. Telefon üreticileri hızla değişen yeni nesil akıllı cep telefonu pazarında çevrenin de etkisiyle tüketicileri bu yeni teknolojiyi satın almaya ve kullanmaya teşvik etmektedir. Teknolojinin hızla gelişmesi ve küreselleşme ile birlikte yeni pazarlama stratejileri müşteri odaklı olarak alan sonsuz müşteri memnuniyeti sayesinde müşteri sadakati oluşturmayı hedeflemektedir. Akın (2017), genç tüketicilerin cep telefonu sektöründe markaya yönelik memnuniyetlerinin marka sadakatlerine etkisinin olup olmadığının araştırmıştır [1]. Atmaca ve Keskin (2014), Türkiye'de GSM operatörlerini kullanan kişiler için müşteri memnuniyeti ile ilgili olarak saha araştırması yapmıştır [2]. Ogba ve Tan (2009), Çin cep telefonu pazarında marka imajının müşteri bağlılı̆̆ını nasıl etkilediğini incelemiştir [27]. Aydın (2004), ülkemizde cep telefonu kullanımları ile GSM operatörlerine karşı tutum ve tercihlerini araştırmışlardır. Ayrıca ankete katılanların seçilmiş demografik özellikleri ile telefon ücretlerini ödeme biçimleri, telefon giderleri, telefon kullanmaya başlama nedenleri ve dönemleri ile tercih nedenleri arasında ilişki olup olmadığını belirlemeye çalışmışlardır [3].

Barutçu (2007), müşteri bağlılığının önemi ile müşteri bağl1lığı ve GSM (Global System for Mobile Communications) operatörlerine bağlılı̆̆ etkileyen faktörleri belirlemeye çalışmıştır [4]. Çalıpınar ve Soysal (2010), iletişim sektöründe faaliyette bulunan bir GSM operatörüne kalite fonksiyon yayılımı yöntemini uygulamıştır [6]. Değerli ve ark. (2015), mobil işletim sistemlerinin (iOS ve Android) birtakım özelliklerinin, kullanıcılar açısından memnuniyeti sağlamada etkisini incelemişlerdir [7]. 
Doğan ve ark., (2015), Kırıkkale Üniversitesi Endüstri Mühendisliği Bölümü öğrencilerine akıllı telefon kullanımı hakkında yapılan anketten elde ettikleri verileri SPSS programı ile çözümleyerek tutarlılığını tespit etmişlerdir. En çok kullanılan iki akıllı telefon markasını oyuncular olarak kabul etmiş ve bu telefonların özelliklerini anket sonuçlarına göre oyun teorisi yaklaşımı ile karşılaştırmışlardır [9]. Durmaz ve Şerbetçi (2016), tüketici davranışları ve bu davranışları etkileyen faktörleri inceleyerek tüketicilerin cep telefonu tercihlerinde etki eden faktörleri ve etki derecelerini belirlemişlerdir [8]. Nasır (2003), GSM operatörü seçiminde kullanıcıların önem verdikleri kriterleri ve kullanılan GSM operatörlerinden memnuniyet düzeylerini belirlemiştir [25]. Özer ve Aydın (2004), GSM sektöründe telefon değiştirme maliyetinin farklı alt boyutlarını kullanarak bir model geliştirmişlerdir. Ayrıca müşteri memnuniyeti ve sadakati, değiştirme maliyeti ve alt boyutları ile güven arasındaki ilişkiyi incelemiştir [28]. Doğru ve Koçer (2016), GSM operatörü kullanıcılarının markalarına olan sadakat eğilimlerini saptayarak, marka sadakatini etkileyen faktörlerin uygulamada geçerliliğini ölçümlemiştir [10]. Dündar ve Fatih (2008), analitik hiyerarşi süreci yöntemiyle üniversite öğrencilerinin cep telefonu hattı satın alımında GSM operatörlerinin (Turkcell, Vodafone, Avea) tercih edilme sıralamasını belirlemiştir [11]. Erkovan (2015), farklı yaş, cinsiyet, meslek grubu ve gelir düzeyine sahip akıllı cep telefonu kullanıcısının bu ürünleri kullanım alışkanlıklarını, kullanımlar ve doyumlar yaklaşımını temel alarak Üsküdar örneği özelinde incelemiştir [12]. Ekren ve Kesim (2016), mobil teknolojilerdeki teknik sınıllılıkların mobil öğrenme deneyimlerinin geliştirilmesine olan etkisini tartışmış ve bu teknolojilerdeki gelişmelerin mobil öğrenmeye sağlayabileceği katkıları değerlendirmiştir [13]. Fettahlıŏlu (2015), akıllı telefonlara ilişkin marka kişiliği algılamaları ve bu algılamanın marka sadakatine etkisini Kahramanmaraş ilinde bulunan tüketiciler üzerinde ele almıştır [14]. Geyik (2015), internet servis sağlayıcıları sektöründe müşterilerin genel eğilimlerini ve müşterilerin satın alma tercihlerinin altında yatan faktörleri belirlemiştir [15]. Gülmez (2005), üniversite öğrencilerinin cep telefonu kullanma ve satın alma davranışlarını etkileyen unsurları tespit etmiştir [16].

Kalyoncuoğlu ve Faiz (2017a), akıllı telefon pazarındaki iki güçlü işletme olan Samsung ve Apple'ın müşteri sadakatini sağlamada müşteri memnuniyetinin, algılanan değerin ve değiştirme maliyetinin etkisini tespit etmiş ve bir model önerisi oluşturmuştur [18]. Kalyoncuoğlu ve Faiz (2017b), Türkiye'de akıllı telefon pazarındaki müşterinin algıladığı değer, değiştirme maliyeti, demografik verileri ve telefon kullanımına ilişkin özellikleri inceleyerek kişinin akıllı telefon kullanımında sadakat geliştirme veya geliştirmeme eğilimini ortaya koymaya çalışmıştır [19]. Korkmaz ve ark., (2015), kurumsal kimliğe sahip "GSM" operatör çalışanlarının sunduğu hizmet kalitesinin müşteri tercih ve memnuniyetleri üzerindeki etkisini incelemiştir [22]. Karagöz ve ark., (2015), öğrencilerin cep telefonu ve operatör tercihlerinde etkili olan değişkenlerin demografik özelliklere bağl1 olarak farklılık gösterip göstermediğini belirlemişlerdir [20]. Karakaş (2012), müşteri sadakati olgusunun bileşenleri olan algılanan kalite, değiştirme maliyeti ve kurumsal imaj değişkenleri arasındaki ilişkileri ve söz konusu bileşenlerin birlikte müşteri sadakati olgusunu açıklamada kullanılan farklı müşteri sadakati modellerini ele alıp yapısal eşitlik modellemesi ile incelemiştir [21]. Kuşku-Özdemir ve Güzeloğlu (2015), gençlerin cep telefonu satın alma kararlarında marka değeri bileşenlerinden hangisinin, ne ölçüde ve daha baskın olarak etkili olduğunu belirlemişlerdir [23].

Marangoz (2007), ağızdan ağıza iletişimin müşterilerin satın alma kararlarına tekrar satın alma ve/veya değiştirme etkilerini incelemiştir [24]. Samsa ve Gelibolu (2015), ilişkisel pazarlama yöntemlerinden hizmet kalitesi ve şirket imajının müşteri memnuniyeti ve müşteri güvenini olumlu yönde etkilediğini belirlemiştir [29]. Şenbabaoğlu ve ark., (2016), GSM operatörleri sektöründe bir araştırma modeli oluşturmuş ve test etmiştir [31]. Şamkar (2017), akıllı telefon kullanıcılarının, akıllı telefon kullanımına ilişkin memnuniyet düzeyleri ve bunda etkili olabilecek faktörleri incelemiştir. Ayrıca 
lojistik regresyon analizi yardımıyla akıllı telefon kullanıcılarının memnuniyet derecelerini belirleyen matematiksel bir model oluşturmuştur [30]. Taner (2014), akıllı telefonların kullanıcıları tarafindan değerlendirmelerini ölçmeye çalışmıştır [32]. Türker ve Türker (2013), marka imajı, markaya güven, müşteri memnuniyeti, algılanan değer, değiştirme maliyeti ve algılanan kalite faktörlerinin marka sadakatine olan etkilerini incelemiştir [34]. Türk ve ark., (2016), GSM operatörlerinin sunmuş oldukları gençlik kampanyalarından gençlerin beklentilerini, mevcut gençlik kampanyalarından ve operatör tercihinden duyulan memnuniyeti ölçmeye yönelik bir araştırma gerçekleştirmiştir [33]. Uzgören, Şengür ve Yiğit (2013), üniversite öğrencilerinin cep telefonu tercih ve kullanımlarında israfa neden olan davranışları ile ilgili değerlendirmeler yapmıştır [35]. Uzgören ve ark., (2015), Dumlupınar Üniversite'sinde öğrenim gören öğrencilerin cep telefonu ilk talebi ile yenileme talebini etkileyen faktörleri anket uygulaması yoluyla belirlemeye çalışmıştır [36]. Uzunkaya (2016), marka sadakatinin tekrar satın alma niyetine etkisini belirlemeye çalışmıştır [37]. Zengin (2010), tüketicilerin mobil pazarlama ve özellikle de SMS pazarlamasına yönelik tutumlarını incelemiştir [39].

\section{UYGULAMA}

\section{A. ARAŞTIRMANIN AMACI VE KAPSAMI}

Bu çalışmanın amacı Kütahya ilinde cep telefonu kullanıcılarının GSM operatörü tercihine etki eden faktörlerin belirlenmesidir. Çalışmada kullanılan ölçek Zanco (2015)'un yapmış olduğu çalışmadan uyarlanarak oluşturulmuştur [38]. Bu çalışmada Zanco tarafından geliştirilen ölçek esas alınarak oluşturulan anket formu ile Kütahya ili sınırları içerisinde GSM kullanıcıları üzerinde bir araştırma gerçekleştirilmiştir. Anket çalışmasından elde edilen veriler istatistik yöntemler kullanılarak analiz edilmiştir. Örnekleme yöntemi olarak kolayda örnekleme yöntemi uygulanmıştır. Araştırma 1 Ocak31 Mart 2019 tarihleri arasında gerçekleştirilmiştir. Ankete 283 kişi katılmış ancak 22 anket verisi uygunsuz ve özensiz olması sebebi ile veri setinden çıkarılmışıı. Anketin güvenilirliği için hesaplanan Cronbach alfa katsayısı 0,957 olarak hesaplanmış olup anketin iç tutarlılığının oldukça iyi olduğu anlaşılmıştır.

\section{B. ANKETE KATILAN KISŞILERIN DEMOGRAFIK ÖZELLİKLERINIIN DAĞILIMI}

Ankete katılan kişilerin cinsiyet ve kullandıkları GSM operatörlerine göre dağılımı aşağıdaki Tablo 1 'de verilmiştir.

Tablo 1. Ankete katılanların cinsiyet ve kullandı̆̆ GSM operatörüne göre dă̆ıllımı

\begin{tabular}{cccccc}
\hline Cinsiyet & Frekans & Yüzde & Operatör & Frekans & Yüzde \\
\hline Kadın & 114 & 43,8 & Vodafone & 100 & 38,5 \\
Erkek & 146 & 56,2 & Turkcell & 90 & 34,6 \\
Toplam & 260 & 100,0 & Türk Telekom & 70 & 26,9 \\
\multicolumn{7}{c}{ Toplam } & 260 & 100,0 \\
\hline \multicolumn{7}{c}{ Cinsiyete Göre Kullanılan } & GSM Operatörünün Dağılımı & Frekans & Yüzde \\
\hline Kadın & Frekans & Yüzde & Erkek & 38 & 26,0 \\
Vodafone & 62 & 54,4 & Vodafone & 54,0 \\
Turkcell & 36 & 31,6 & Turkcell & 54 & 37,0 \\
Türk Telekom & 16 & 14,0 & Türk Telekom & 146 & 100,0 \\
Toplam & 114 & 100,0 & Toplam
\end{tabular}


Tablo 1'de görülüyor ki; ankete katılanların yaklaşık \%44'ünü kadınlar, \%56'sını erkekler oluşturmaktadır. Katılımcıların kullandıkları GSM operatörlerine göre dağılımı \%38,5 Vodafone, \%34,6 Turkcell ve \%26,9’u ise Türk Telekom şeklindedir. Dağıllım incelendiğinden dengeli olduğu ve tüm operatörleri temsil edebilecek nitelikte olduğu anlaşılmaktadır. Ayrıca katılımcıların cinsiyete göre GSM operatörü kullanımları incelendiğinde kadınların \%54,4 Vodafone, \%31,6's1 Turkcell ve \%14'ü ise Türk Telekom kullandığı, erkeklerin ise \%26'sı Vodafone, \%37'si Turkcell ve \%37'si ise Türk Telekom kullandığ 1 görülmektedir.

\section{IV.BULGULAR VE ANALIZLLER}

Araştırmaya katılan kullanıcıların GSM operatörü tercihini etkileyen faktörler ile ilgili olarak duygu, düşünce ve algıları istatistik tekniklerle analiz edilmiş ve sonuçlar aşağıda verilmiştir.

\section{A. KULLANICILARIN GSM OPERATÖRÜ TERCIHINİ ETKILEYEN FAKTÖRLER İÇIN BETIMLEYICİ İSTATISTIKLER}

Bilindiği gibi Türkiye'de 3 GSM operatörü bulunmaktadır. Kullanıcıların bu operatörleri seçme nedenleri için betimsel istatistikler aşağıdaki Tablo 2'de verilmiştir.

Tablo 2. Kullanıcıların operatör seçme nedenleri için betimsel istatistikler

\begin{tabular}{|c|c|c|c|c|}
\hline GSM Operatörünü Tercih Sebepleri & Ortalama & Std. Sapma & Çarpıklık & Basıklık \\
\hline Sunulan tüm hizmet merkezleri modern donanıma sahiptir. & 2,977 & 1,303 & 0,022 & $-1,117$ \\
\hline Tüm hizmet merkezleri görsel açıdan çekicidir. & 3,100 & 1,236 & $-0,216$ & $-0,946$ \\
\hline Hizmet merkezlerinin çalışanları temiz ve iyi görünümlüdür. & 3,231 & 1,199 & $-0,196$ & $-0,833$ \\
\hline $\begin{array}{l}\text { Hizmet merkezlerinin çalışanları verdikleri sözleri zamanında yerine } \\
\text { getirir. }\end{array}$ & 3,204 & 1,243 & $-0,198$ & $-0,959$ \\
\hline $\begin{array}{l}\text { Hizmet merkezlerinin çalışanları müşterilerinin sorunlarıyla yakından ve } \\
\text { samimi bir şekilde ilgilenir }\end{array}$ & 3,319 & 1,173 & $-0,498$ & $-0,594$ \\
\hline Verilen hizmetler ilk seferde doğru bir şekilde yerine getirilir. & 3,339 & 1,186 & $-0,247$ & $-0,814$ \\
\hline Verilen hizmetler söz verdiği zamanda yerine getirilir. & 3,296 & 1,189 & $-0,146$ & $-0,606$ \\
\hline $\begin{array}{l}\text { Hizmet merkezlerinin çalışanları müşterilere sundukları hizmetleri hızlı } \\
\text { bir şekilde yerine getirir. }\end{array}$ & 3,281 & 1,123 & $-0,423$ & $-0,609$ \\
\hline Hizmet merkezlerinin çalışanları müşterilerine güven duygusu verir. & 3,335 & 1,076 & $-0,418$ & $-0,337$ \\
\hline $\begin{array}{l}\text { Hizmet merkezlerinin çalışanları müşterilerine karş1 her zaman sayg1 } \\
\text { çerçevesinde hizmet verir. }\end{array}$ & 3,481 & 1,113 & $-0,476$ & $-0,578$ \\
\hline $\begin{array}{l}\text { Hizmet merkezlerinin çalışanları ürün ve hizmetler konusunda yeterli } \\
\text { bilgi ve donanıma sahiptir. }\end{array}$ & 3,496 & 1,092 & $-0,384$ & $-0,569$ \\
\hline $\begin{array}{l}\text { Hizmetlerde meydana gelen değişiklikleri müşterilerine zamanında } \\
\text { bildirir }\end{array}$ & 3,450 & 1,109 & $-0,344$ & $-0,403$ \\
\hline $\begin{array}{l}\text { Hizmet merkezlerinin çalışanları müşterilerine yardımcı olmak için her } \\
\text { zaman istekli ve gönüllüdür }\end{array}$ & 3,450 & 1,088 & $-0,442$ & $-0,359$ \\
\hline Hizmet merkezlerinin çalışanları müşterileriyle tek tek ilgilenir. & 3,392 & 1,108 & $-0,309$ & $-0,614$ \\
\hline Hizmet merkezleri müşterileri için uygun çalışma saatlerine sahiptir. & 3,458 & 1,137 & $-0,364$ & $-0,666$ \\
\hline $\begin{array}{l}\text { Hizmet merkezlerinin çalışanları müşterilerinin özel istek ve ihtiyaçlarını } \\
\text { anlar. }\end{array}$ & 3,342 & 1,244 & $-0,418$ & $-0,839$ \\
\hline Müşterilerinin çıkarlarını ön planda tutulur & 3,523 & 1,127 & $-0,4$ & $-0,465$ \\
\hline Hizmetler sözleşmede belirtilen tarifeler üzerinden ücretlendirir & 3,277 & 1,315 & $-0,4$ & $-0,924$ \\
\hline $\begin{array}{l}\text { Hizmet fiyatlarında meydana gelen değişiklikleri müşterilerine } \\
\text { zamanında bildirir. }\end{array}$ & 3,358 & 1,145 & $-0,454$ & $-0,557$ \\
\hline Çağrı/SMS/MMS fiyatları uygundur. & 3,408 & 1,167 & $-0,443$ & $-0,615$ \\
\hline
\end{tabular}


Tablo 2 (devamı). Kullanıcıların operatör seçme nedenleri için betimsel istatistikler

\begin{tabular}{|c|c|c|c|c|}
\hline Hat fiyatları uygundur. & 3,269 & 1,275 & $-0,224$ & $-1,027$ \\
\hline Uygun tarife avantajlarına sahiptir. & 3,515 & 1,154 & $-0,569$ & $-0,447$ \\
\hline İnternet servis paket fiyatları uygundur. & 3,269 & 1,337 & $-0,298$ & $-1,038$ \\
\hline Yurtdışında kullanım paket fiyatları uygundur. & 2,915 & 1,208 & $-0,022$ & $-0,81$ \\
\hline Yurtdışını arama paket fiyatları uygundur. & 2,996 & 1,263 & $-0,074$ & $-0,921$ \\
\hline Etkileyici reklam tekliflerine sahiptir. & 3,185 & 1,168 & $-0,277$ & $-0,712$ \\
\hline Reklam sayıs1 yeterlidir. & 3,342 & 1,074 & $-0,321$ & $-0,456$ \\
\hline Yaratıcı reklamlara sahiptir. & 3,335 & 1,101 & $-0,431$ & $-0,445$ \\
\hline Bilgi verici ve aydınlatıcıdır. & 3,473 & 1,106 & $-0,501$ & $-0,367$ \\
\hline Reklamlar açık ve anlaşılırdır. & 3,523 & 1,187 & $-0,614$ & $-0,412$ \\
\hline Her kesime hitap etmektedir. & 3,492 & 1,127 & $-0,6$ & $-0,22$ \\
\hline Reklamlar tüm müşteri kitlesine hitap edecek kadar zengindir. & 3,585 & 1,204 & $-0,602$ & $-0,49$ \\
\hline Geniş bir kapsama alanına sahiptir. & 3,350 & 1,191 & $-0,4$ & $-0,753$ \\
\hline $\begin{array}{l}\text { En son teknolojiyi takip eder ve bu teknolojik yenilikleri hizmetlerine } \\
\text { yansitır. }\end{array}$ & 3,454 & 1,102 & $-0,606$ & $-0,143$ \\
\hline Metro, otopark gibi alanlarda çekmektedir. & 3,327 & 1,117 & $-0,271$ & $-0,651$ \\
\hline Kesintisiz konuşma sağlamaktadır. & 3,362 & 1,208 & $-0,566$ & $-0,494$ \\
\hline Ses kalitesi iyidir & 3,489 & 1,099 & $-0,533$ & $-0,362$ \\
\hline İnternet hizmeti hızlıdır. & 3,419 & 1,155 & $-0,461$ & $-0,472$ \\
\hline 4,5G Hizmetinin ses ve görüntü kalitesi iyidir. & 3,358 & 1,195 & $-0,337$ & $-0,867$ \\
\hline Aile ve akrabalarım tarafından kullanılması önemlidir. & 3,185 & 1,248 & $-0,222$ & $-0,936$ \\
\hline Arkadaşlarım tarafından kullanılması önemlidir. & 3,446 & 1,150 & $-0,382$ & $-0,588$ \\
\hline İş arkadaşlarım tarafından kullanılması önemlidir & 3,512 & 1,216 & $-0,514$ & $-0,595$ \\
\hline
\end{tabular}

Tablo 3'de görülüyor ki; cep telefonu kullanıcılarının geneli için GSM operatörü tercihinde etkili faktörler incelendiğinde çok fazla öne çıkmış bir faktör görülmemiştir. Bununla birlikte reklamların, müşteri çıkarlarını önceliklendirme, uygun tarife avantajlarının, açık ve anlaşılırlığın, arkadaşları tarafından tercih ediliyor olma faktörlerinin GSM operatörü tercihinde nispi olarak öne çıktığı söylenebilir.

GSM kullanıcılarının kullanmış oldukları operatörü tercih etme sebeplerini araştırmak için toplanan veriler için yapılan Kolmogorov Smirnov, Anderson Darling, Shapiro Wilk testlerine göre verilerin normal dağılım göstermediği anlaşılmıştır. Ancak anket verilerinde bu durum sıklıkla karşılaşılan bir sonuçtur. Bu sebeple verinin normalliğini betimleyici istatistikleri dikkate alarak belirleme yoluna gidilmektedir. Verinin normalliği için çarpıklık ve basıklık değerlerinin standart hatalarına oranlarının \pm 2 aralığında olması uygun görülmektedir [26]. Bu özellik verilerimizde mevcuttur. Buna dayanarak verilerin analizinde parametrik test yaklaşımı kullanılmıştır.

\section{B. KULLANICININ CINSIYYET VE KULLANDIĞI GSM OPERATÖRÜNE GÖRE HIZMET ALGISININ ARAŞTIRILMASI}

GSM kullanıcılarının aldıkları hizmetlerin cinsiyet ve operatör faktörüne göre farklılık gösterip göstermediği t testi ve varyans analizi ile araştırılmıştır.

\section{B.1. Cinsiyetine Göre GSM Operatörlerinden Aldığı Hizmet Algısının Değişimi}

Aşağıdaki Tablo 3'de kadın ve erkek kullanıcıların GSM operatörlerinden aldıkları hizmetlerden algılarının farkı için $t$ testi sonuçları verilmiştir. Tabloda önemli farklılıklar gösteren hizmetler verilmiştir. 
Tablo 3. Müşterinin Cinsiyetine Göre Hizmet Algısının Farkı Iç̧in t testi

\begin{tabular}{lcccc}
\hline \multirow{2}{*}{ Hizmet } & \multicolumn{3}{c}{ Ortalamaların eşitliği için t testi } \\
\cline { 2 - 5 } & $\mathbf{t}$ & S.d & $\begin{array}{c}\text { Anlamlılık } \\
\text { (çift taraflı) }\end{array}$ & $\begin{array}{c}\text { Ortalamaların farkı } \\
\text { (Kadın- Erkek) }\end{array}$ \\
\hline Sunulan tüm hizmet merkezleri modern donanıma sahiptir. & $-1,96$ & 258 & 0,051 & $-0,318$ \\
Tüm hizmet merkezleri görsel açıdan çekicidir. & $-2,91$ & 258 & 0,004 & $-0,444$ \\
Hizmet merkezlerinin çalışanları verdikleri sözleri zamanında & $-2,25$ & 258 & 0,025 & $-0,347$ \\
yerine getirir. & $-2,19$ & 258 & 0,03 & $-0,322$ \\
Verilen hizmetleri ilk seferinde doğru olarak yerine getirmesi & $-2,6$ & 258 & 0,01 & $-0,372$ \\
İnternet hizmeti hızlıdır. & & & & \\
\hline
\end{tabular}

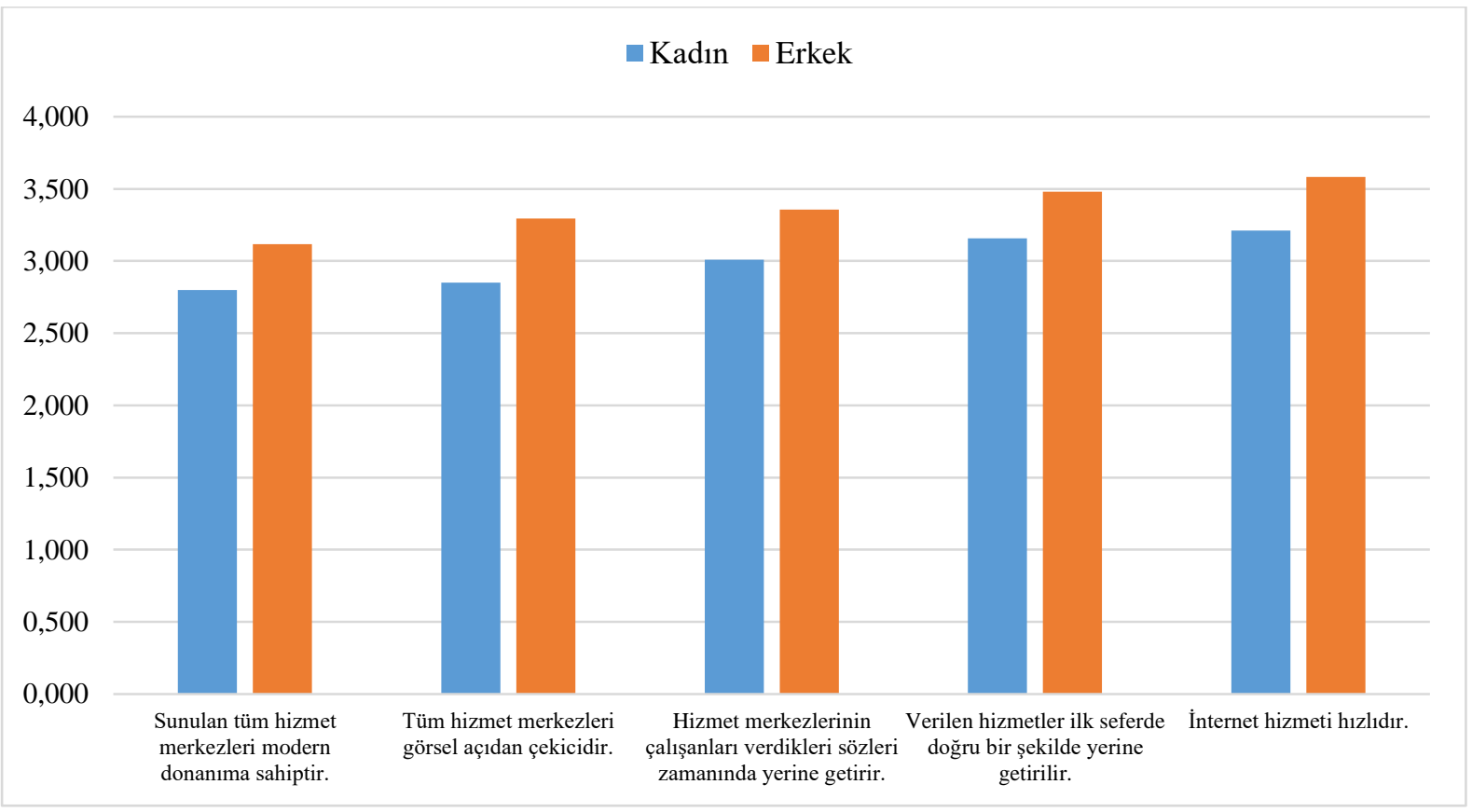

Şekil 1. Cinsiyetine göre GSM operatörlerinden aldı̆̆ hizmet algısının değişimi

Tablo 3 ve Şekil 1'de görülüyor ki; kadın ve erkeklerin farklı algıladıkları hizmet türleri verilmiştir. Diğer hizmetlerden iki grubun algıları arasında önemli bir fark yoktur. Tablo ve grafikten görülmektedir ki hizmet merkezlerinin modern donanıma sahip olması, görsel açıdan çekici olması, çalışanların verdikleri sözleri zamanında yerine getirmeleri, hizmetleri ilk seferde doğru yapmaları ve internet hizmetinin hızı ile ilgili hizmetleri erkekler kadınlara göre daha fazla önemsemektedirler.

\section{B.2. GSM Operatörüne Göre Hizmet Algısının Değişimi}

GSM Operatörü kullanıcılarının hizmet aldıkları operatörün hizmetlerine verdikleri ortalama puanlar Tablo 4'te verilmiştir.

Tablo 4. GSM operatörü kullanıcılarının operatörünün hizmetlerine verdikleri ortalama puanlar

\begin{tabular}{lcccc}
\hline \multicolumn{1}{c}{ GSM operatörü kullanıcılarının aldıkları hizmetler } & Vodafone & Turkcell & Türk Telekom & Toplam \\
\hline Sunulan tüm hizmet merkezleri modern donanıma sahiptir. & 2,89 & 2,99 & 3,09 & 2,98 \\
\hline Tüm hizmet merkezlerinin görsel açıdan çekici olması. & 2,87 & 3,20 & 3,30 & 3,10 \\
\hline
\end{tabular}


Tablo 4 (devamı). GSM operatörü kullanıcılarının operatörünün hizmetlerine verdikleri ortalama

\begin{tabular}{|c|c|c|c|c|}
\hline Hizmet merkezlerinin çalışanlarının temiz ve iyi görünümlü olması. & 3,04 & 3,41 & 3,27 & 3,23 \\
\hline $\begin{array}{l}\text { Hizmet merkezlerinin çalışanları verdikleri sözleri zamanında yerine } \\
\text { getirir. }\end{array}$ & 3,05 & 3,22 & 3,40 & 3,20 \\
\hline $\begin{array}{l}\text { Hizmet merkezlerinin çalışanları müşterilerinin sorunlarıyla yakından } \\
\text { ve samimi bir şekilde ilgileniyor olması. }\end{array}$ & 3,21 & 3,43 & 3,33 & 3,32 \\
\hline Verilen hizmetlerin ilk seferde doğru bir şekilde yerine getirilmesi. & 3,38 & 3,24 & 3,40 & 3,34 \\
\hline Verilen hizmetlerin söz verildiği zamanda yerine getirilmesi. & 3,21 & 3,38 & 3,31 & 3,30 \\
\hline $\begin{array}{l}\text { Hizmet merkezlerinin çalışanları müşterilere sundukları hizmetleri hızlı } \\
\text { bir şekilde yerine getirmesi. }\end{array}$ & 3,11 & 3,33 & 3,46 & 3,28 \\
\hline Hizmet merkezlerinin çalışanları müşterilerine güven duygusu verir. & 3,15 & 3,49 & 3,40 & 3,33 \\
\hline $\begin{array}{l}\text { Hizmet merkezlerinin çalışanları müşterilerine karşı her zaman sayg1 } \\
\text { çerçevesinde hizmet verir. }\end{array}$ & 3,38 & 3,57 & 3,51 & 3,48 \\
\hline $\begin{array}{l}\text { Hizmet merkezlerinin çalışanları ürün ve hizmetler konusunda yeterli } \\
\text { bilgi ve donanıma sahiptir. }\end{array}$ & 3,48 & 3,72 & 3,23 & 3,50 \\
\hline $\begin{array}{l}\text { Hizmetlerde meydana gelen değişiklikleri müşterilerine zamanında } \\
\text { bildirir }\end{array}$ & 3,29 & 3,66 & 3,41 & 3,45 \\
\hline $\begin{array}{l}\text { Hizmet merkezlerinin çalışanları müşterilerine yardımcı olmak için her } \\
\text { zaman istekli ve gönüllüdür }\end{array}$ & 3,22 & 3,51 & 3,70 & 3,45 \\
\hline Hizmet merkezlerinin çalışanları müşterileriyle tek tek ilgilenir. & 3,15 & 3,58 & 3,50 & 3,39 \\
\hline Hizmet merkezleri müşterileri için uygun çalışma saatlerine sahiptir. & 3,37 & 3,60 & 3,40 & 3,46 \\
\hline $\begin{array}{l}\text { Hizmet merkezlerinin çalışanları müşterilerinin özel istek ve } \\
\text { ihtiyaçlarını anlar. }\end{array}$ & 3,32 & 3,49 & 3,19 & 3,34 \\
\hline Müşterilerin çıkarları ön planda tutulur & 3,41 & 3,73 & 3,41 & 3,52 \\
\hline Hizmetler sözleşmede belirtilen tarifeler üzerinden ücretlendirir & 3,12 & 3,36 & 3,40 & 3,28 \\
\hline $\begin{array}{l}\text { Hizmet fiyatlarında meydana gelen değişiklikleri müşterilerine } \\
\text { zamanında bildirir. }\end{array}$ & 3,06 & 3,62 & 3,44 & 3,36 \\
\hline Çağr1/SMS/MMS fiyatları uygundur. & 3,40 & 3,50 & 3,30 & 3,41 \\
\hline Hat fiyatları uygundur. & 3,09 & 3,50 & 3,23 & 3,27 \\
\hline Uygun tarife avantajlarına sahiptir. & 3,50 & 3,52 & 3,53 & 3,52 \\
\hline İnternet servis paket fiyatlarının uygun olması. & 3,27 & 3,31 & 3,21 & 3,27 \\
\hline Yurtdışında kullanım paket fiyatlarının uygun olması. & 2,84 & 3,08 & 2,81 & 2,92 \\
\hline Yurtdışını arama paket fiyatlarının uygun olması. & 2,85 & 3,02 & 3,17 & 3,00 \\
\hline Etkileyici reklam tekliflerine sahiptir. & 3,01 & 3,40 & 3,16 & 3,18 \\
\hline Reklam sayıs1 yeterlidir. & 3,14 & 3,60 & 3,30 & 3,34 \\
\hline Yaratıcı reklamlara sahiptir. & 3,20 & 3,41 & 3,43 & 3,33 \\
\hline Bilgi verici ve aydınlatıcıdır. & 3,36 & 3,52 & 3,57 & 3,47 \\
\hline Reklamlar açık ve anlaşılırdır. & 3,34 & 3,49 & 3,83 & 3,52 \\
\hline Her kesime hitap etmektedir. & 3,39 & 3,56 & 3,56 & 3,49 \\
\hline Reklamlar tüm müşteri kitlesine hitap edecek kadar zengindir. & 3,36 & 3,62 & 3,86 & 3,58 \\
\hline Geniş bir kapsama alanına sahiptir. & 3,24 & 3,44 & 3,39 & 3,35 \\
\hline $\begin{array}{l}\text { En son teknolojiyi yakından takip etmesi ve teknolojik yenilikleri } \\
\text { hizmetlerine yansıtması. }\end{array}$ & 3,36 & 3,46 & 3,59 & 3,45 \\
\hline Metro, otopark gibi alanlarda çekmektedir. & 3,07 & 3,47 & 3,51 & 3,33 \\
\hline Kesintisiz konuşma sağlamaktadır. & 3,12 & 3,56 & 3,46 & 3,36 \\
\hline Ses kalitesi iyidir & 3,39 & 3,56 & 3,54 & 3,49 \\
\hline İnternet hizmeti hizlıdır. & 3,13 & 3,50 & 3,73 & 3,42 \\
\hline 4,5G Hizmetinin ses ve görüntü kalitesi iyidir. & 3,18 & 3,38 & 3,59 & 3,36 \\
\hline Aile ve akrabalarım tarafindan kullanılıyor olması önemlidir. & 3,16 & 3,20 & 3,20 & 3,18 \\
\hline Arkadaşlarım tarafından kullanılıyor olması önemlidir. & 3,40 & 3,41 & 3,56 & 3,45 \\
\hline İş arkadaşlarım tarafindan kullanılıyor olması önemlidir & 3,49 & 3,49 & 3,57 & 3,51 \\
\hline
\end{tabular}

Tablo 5'e göre Vodafone kullanıcıları uygun tarife avantajlarını, iş arkadaşları tarafindan kullanılıyor olmasını ve hizmet merkezi çalışanlarının ürün ve hizmetler konusunda yeterli bilgiye sahip olmasını öne çıkarmışlardır. Türkcell kullanıcıları müşteri çıkarlarının ön planda tutulmasını, hizmet merkezi çalışanlarının ürün ve hizmetler konusunda yeterli bilgiye sahip olmasını, Hizmetlerde meydana gelen değişiklikleri müşterilere zamanında bildirilmesini daha çok önemsemişlerdir. Türk Telekom 
kullanıcıları reklamların tüm müşteri kitlesine hitap edecek kadar zengin olmasını, reklamların açık ve anlaşı1ır olmasını, internet hizmetlerinin hızlı olmasını daha yüksek puanlamışlardır.

Varyans analizi ile mevcut 3 GSM operatörün kullanıcılarının aldıkları hizmetlerle ilgili algılarının farklılığı araştırılmıştır. Aşağıda buna ilişkin varyans analizi tablosu verilmiştir.

Tablo 5. Farklı GSM operatörü kullanıcılarının aldıkları hizmetlerle ilgili algılarının analizi

\begin{tabular}{|c|c|c|c|c|c|c|}
\hline \multicolumn{2}{|c|}{ Kullanıcılarının aldıkları hizmetlerle ilgili algıları } & \multirow{2}{*}{$\begin{array}{c}\begin{array}{c}\text { Kareler } \\
\text { toplamı }\end{array} \\
8,9\end{array}$} & \multirow{2}{*}{ S.d } & \multirow{2}{*}{$\begin{array}{c}\begin{array}{c}\text { Kareler } \\
\text { ortalama }\end{array} \\
4,495\end{array}$} & \multirow{2}{*}{$\frac{F}{2,99}$} & \multirow{2}{*}{$\frac{\text { Anlamlilik }}{, 05^{*}}$} \\
\hline 1- Tüm hizmet merkezlerinin görsel açıdan çekici & G. içi & & & & & \\
\hline olmasi. & G. aras1 & 386,41 & 257 & 1,504 & & \\
\hline & Toplam & 395,40 & 259 & & & \\
\hline \multirow{3}{*}{$\begin{array}{l}\text { 2- Hizmet merkezlerinin çalışanları ürün ve } \\
\text { hizmetler konusunda yeterli bilgiye sahiptir. }\end{array}$} & G. içi & 9,64 & 2 & 4,819 & 4,13 &, $017 *$ \\
\hline & G. aras1 & 299,35 & 257 & 1,165 & & \\
\hline & Toplam & 308,99 & 259 & & & \\
\hline \multirow{3}{*}{$\begin{array}{l}\text { 3- Hizmet merkezlerinde çalışanların müşterilere } \\
\text { yardımcı olmak için her zaman istekli ve gönüllü } \\
\text { olması }\end{array}$} & G. içi & 10,00 & 2 & 5,001 & 4,33 &, $014 *$ \\
\hline & G. aras1 & 296,35 & 257 & 1,153 & & \\
\hline & Toplam & 306,35 & 259 & & & \\
\hline \multirow{3}{*}{$\begin{array}{l}\text { 4- Hizmet merkezlerinin çalışanları müşterileriyle } \\
\text { tek tek ilgilenir. }\end{array}$} & G. içi & 9,78 & 2 & 4,890 & 4,07 &, $018^{*}$ \\
\hline & G. aras1 & 308,20 & 257 & 1,199 & & \\
\hline & Toplam & 317,98 & 259 & & & \\
\hline \multirow{3}{*}{$\begin{array}{l}\text { 5- Hizmet fiyatlarında meydana gelen değişimleri } \\
\text { müşteriler zamanında bildirmesi. }\end{array}$} & G. içi & 15,67 & 2 & 7,834 & 6,21 &, $002 * *$ \\
\hline & G. aras1 & 324,07 & 257 & 1,261 & & \\
\hline & Toplam & 339,74 & 259 & & & \\
\hline \multirow[t]{3}{*}{ 6- Reklam say1s1 yeterlidir. } & G. içi & 10,19 & 2 & 5,097 & 4,54 &, $012^{*}$ \\
\hline & G. aras1 & 288,34 & 257 & 1,122 & & \\
\hline & Toplam & 298,53 & 259 & & & \\
\hline \multirow[t]{3}{*}{ 7- Reklamlar Açık ve anlaşılırdır. } & G. içi & 9,99 & 2 & 4,995 & 3,61 & ,028* \\
\hline & G. aras1 & 354,87 & 257 & 1,381 & & \\
\hline & Toplam & 364,86 & 259 & & & \\
\hline 8- Reklamlar tüm müşteri kitlesine hitap edecek & G. içi & 10,37 & 2 & 5,186 & 3,65 &, $027 *$ \\
\hline \multirow[t]{2}{*}{ kadar zengindir. } & G. aras1 & 364,76 & 257 & 1,419 & & \\
\hline & Toplam & 375,13 & 259 & & & \\
\hline \multirow[t]{3}{*}{ 9- Metro, otopark gibi alanlarda çekmektedir. } & G. içi & 10,82 & 2 & 5,408 & 4,44 &, $013 *$ \\
\hline & G. $\operatorname{aras} 1$ & 312,39 & 257 & 1,216 & & \\
\hline & Toplam & 323,21 & 259 & & & \\
\hline \multirow[t]{3}{*}{ 10- Kesintisiz konuşma sağlamaktadır. } & G. içi & 9,86 & 2 & 4,931 & 3,44 &, $033 *$ \\
\hline & G. aras1 & 368,15 & 257 & 1,433 & & \\
\hline & Toplam & 378,01 & 259 & & & \\
\hline \multirow[t]{3}{*}{ 11- İnternet hizmeti hızlıdır. } & G. içi & 15,65 & 2 & 7,825 & 6,10 &, $003 * *$ \\
\hline & G. aras1 & 329,65 & 257 & 1,283 & & \\
\hline & Toplam & 345,30 & 259 & & & \\
\hline
\end{tabular}

$(*) \% 5,(* *) \% 1$ anlam düzeyinde önemli 


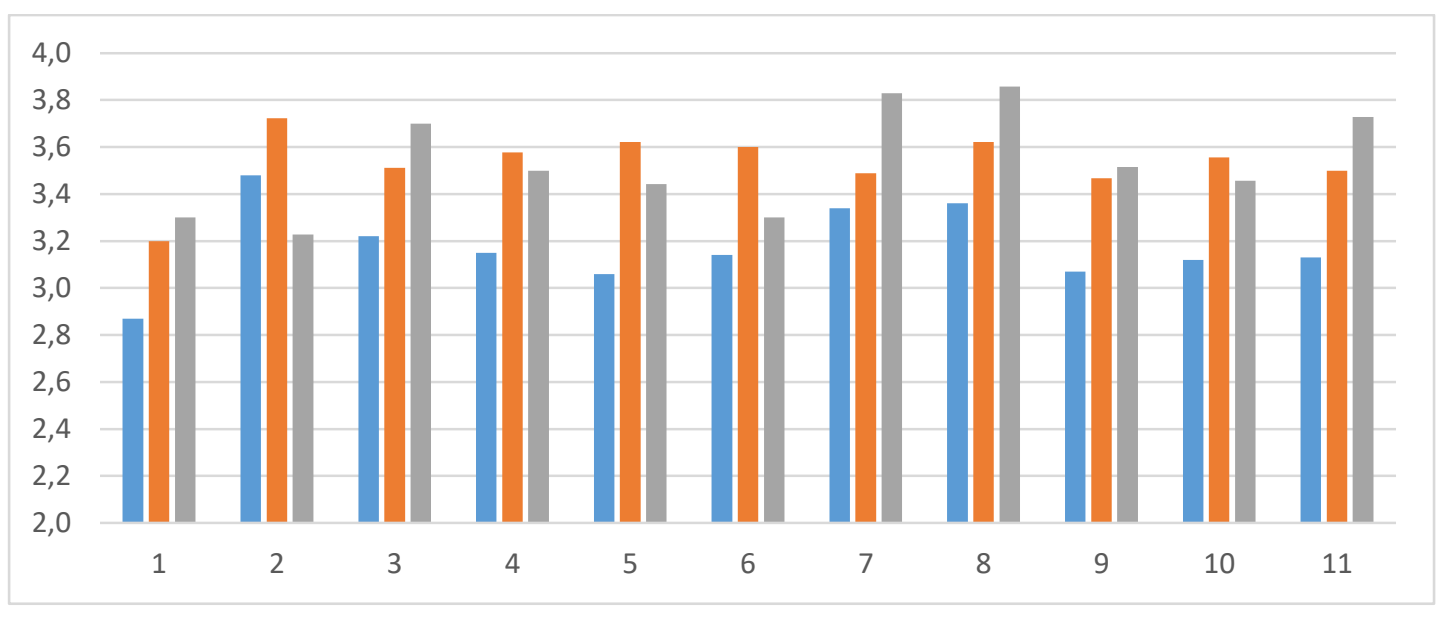

Şekil 2. Müşteri Algıslnın Operatörlere Göre Farklllık Gösterdiği Hizmetler

Şekil 2'de görülüyor ki; GSM kullanıcılarının operatörlere göre farklı algıladığı hizmetler için varyans analizi tablosu ve grafiği verilmiştir. Operatörlere göre farklılık göstermeyen hizmetlere tabloda yer verilmemiştir. Varyans analizine göre 42 hizmet türünden 31 tanesinde müşteri algısının operatörlere göre farkl1lık göstermediği, sadece 11 hizmet türünde farkl1lık görülmüştür. Hemen tüm bu 11 hizmet türünde operatörlerden biri daha öne çıkmıştır.

\section{B.3. Verinin Faktör Yapısının Araştırılması}

Veri setinin faktör analizi için uygunluğunu araştırmak için Bartlett küresellik ve Kaiser Meyer Olkin (KMO) örnelem yeterliliği testi uygulanmış ve sonuçlar aşağıda verilmiştir. Kaiser Meyer Olkin (KMO) değeri değişkenler tarafından oluşturulan ortak varyansı ifade etmekte olup bu değerin 1' e yakın olması uygundur. Bu değer veri grubu için 0,905 olarak bulunmuş olup verinin faktör analizine oldukça uygun olduğuna işaret etmektedir. Diğer yandan Bartlett değeri değişkenlerin kendi aralarında korelasyon gösterip göstermediğini araştırmak için kullanılır. Bu değerin de anlamlı olmaması yani değişkenlerin kendi aralarında ilişkili olmaması gerekmektedir ki bu özellik de veri grubunda mevcuttur. Her iki test için sonuçlar aşağıdaki Tablo 6'da verilmiştir.

Tablo 6. Cronbach alfa, KMO ve Bartlett testi

\begin{tabular}{lcc}
\hline & Cronbach Alfa & 0,957 \\
\multicolumn{2}{c}{ Kaiser-Meyer-Olkin Örneklem yeterliliği Ölçüsü. } & 905 \\
\cline { 2 - 3 } Bartlett Küresellik Test & Ki-Kare & 7062,519 \\
\cline { 2 - 3 } & Serbestlik derecesi & 861 \\
\hline
\end{tabular}

Tablo 6'ya göre Bartlett's küresellik testi için Ki-kare=7062,5 ve olasıllı̆ 1 ise 0,000 bulunmuştur. Elde edilen değerlere göre korelasyon matrisinin birim matris olmadığ 1 ve faktör çıkarılabilir bir yapıda olduğu anlaşılmıştır. Sonuç olarak yapılan anazlizde verinin faktör analizi için yeterli ve uygun olduğu tespit edilmiştir. 
Tablo 7. Başlangıç açılklanan toplam varyans tablosu

\begin{tabular}{|c|c|c|c|c|c|c|c|c|c|}
\hline \multirow[b]{2}{*}{ Bileşen } & \multicolumn{3}{|c|}{ Başlangıç Özdeğerler } & \multicolumn{3}{|c|}{ Yüklerin Kareleri toplamı } & \multicolumn{3}{|c|}{ Döndürülmüş Yüklerin Kareleri Toplamı } \\
\hline & Toplam & $\begin{array}{c}\text { Varyans } \\
\% \text { 'si }\end{array}$ & Kümülatif \% & Toplam & $\begin{array}{c}\text { Varyans } \\
\text { \%'si }\end{array}$ & $\begin{array}{c}\text { Kümülatif } \\
\%\end{array}$ & Toplam & $\begin{array}{c}\text { Varyans } \\
\% \text { 'si }\end{array}$ & $\begin{array}{c}\text { Kümülatif } \\
\%\end{array}$ \\
\hline 1 & 15,459 & 36,808 & 36,808 & 15,459 & 36,808 & 36,808 & 4,361 & 10,383 & 10,383 \\
\hline 2 & 2,535 & 6,036 & 42,844 & 2,535 & 6,036 & 42,844 & 4,345 & 10,345 & 20,728 \\
\hline 3 & 2,010 & 4,785 & 47,630 & 2,010 & 4,785 & 47,630 & 3,977 & 9,468 & 30,196 \\
\hline 4 & 1,803 & 4,294 & 51,923 & 1,803 & 4,294 & 51,923 & 3,576 & 8,514 & 38,709 \\
\hline 5 & 1,526 & 3,633 & 55,557 & 1,526 & 3,633 & 55,557 & 2,778 & 6,615 & 45,324 \\
\hline 6 & 1,499 & 3,569 & 59,126 & 1,499 & 3,569 & 59,126 & 2,705 & 6,441 & 51,764 \\
\hline 7 & 1,307 & 3,111 & 62,237 & 1,307 & 3,111 & 62,237 & 2,564 & 6,106 & 57,870 \\
\hline 8 & 1,146 & 2,728 & 64,965 & 1,146 & 2,728 & 64,965 & 2,119 & 5,044 & 62,914 \\
\hline 9 & 1,033 & 2,460 & 67,425 & 1,033 & 2,460 & 67,425 & 1,894 & 4,511 & 67,425 \\
\hline 10 & ,996 & 2,372 & 69,797 & & & & & & \\
\hline 11 & 951 & 2,265 & 72,061 & & & & & & \\
\hline 12 & 878 & 2,091 & 74,152 & & & & & & \\
\hline
\end{tabular}

Tüm değişkenler faktör analizine tabi tutulduğunda 9 faktörlü bir yapı oluşmakta ve bu yapı toplam varyansın \%67,42'sini açıklayabilmektedir. Ancak faktör yükleri incelendiğinde bazı değişkenlerin 0,5'i altında kalması ya da iki veya daha fazla faktör altında toplanıyor olması gibi sorunlarla karşılaşılmıştır. Bu tür problemlere sebep olan değişkenler modelden çıkarılarak yeniden faktör analizi uygulaması yapılmış ve aşağıdaki sonuçlar elde edilmiştir.

Tablo 8. KMO ve Bartlett testi

\begin{tabular}{ccc}
\hline \multicolumn{2}{c}{ Kaiser-Meyer-Olkin Örnekleme Yeterliliği Ölçüsü } &, 906 \\
\cline { 2 - 3 } Bartlett Küresellik Testi & Ki-kare & 6254,320 \\
\cline { 2 - 3 } & Serbestlik derecesi & 703 \\
\cline { 2 - 3 } & Anlamlılı & 000 \\
\hline
\end{tabular}

Tablo 8' deki KMO ve Bartlett testine göre verinin faktör analizi için uygun olduğu anlaşılmaktadır. Böylece kalan değişkenler için faktör analizi uygulanmış ve sonuçlar aşağıda verilmiştir.

Tablo 9. Faktörler tarafindan açıklanan toplam varyans tablosu

\begin{tabular}{|c|c|c|c|c|c|c|c|c|c|}
\hline \multirow{2}{*}{ Bileşen } & \multicolumn{3}{|c|}{ Başlangıç özdeğerler } & \multicolumn{3}{|c|}{ Yüklerin Kareleri toplamı } & \multicolumn{3}{|c|}{$\begin{array}{c}\text { Döndürülmüş Yüklerin Kareleri } \\
\text { toplamı }\end{array}$} \\
\hline & Toplam & $\begin{array}{c}\text { Varyans } \\
\% \text { 'si }\end{array}$ & Kümülatif \% & Toplam & $\begin{array}{c}\text { Varyans } \\
\% \text { 'si }\end{array}$ & $\begin{array}{c}\text { Kümülatif } \\
\%\end{array}$ & Toplam & $\begin{array}{c}\text { Varyans } \\
\% \text { 'si }\end{array}$ & $\begin{array}{c}\text { Kümülatif } \\
\%\end{array}$ \\
\hline 1 & 14,260 & 37,526 & 37,526 & 14,260 & 37,526 & 37,526 & 3,916 & 10,305 & 10,305 \\
\hline \multicolumn{10}{|c|}{ Tablo 9. Faktörler tarafindan açıklanan toplam varyans tablosu } \\
\hline$J$ & 1,oנU & $4,0 J \angle$ & $40,14 J$ & 1,0 oju & $4,0 J \angle$ & $40,14 J$ & $\jmath,+4 \jmath$ & ᄀ, vuv & $\angle 0, J u J$ \\
\hline 4 & 1,716 & 4,517 & 53,260 & 1,716 & 4,517 & 53,260 & 3,359 & 8,839 & 37,404 \\
\hline 5 & 1,477 & 3,888 & 57,147 & 1,477 & 3,888 & 57,147 & 2,771 & 7,293 & 44,697 \\
\hline 6 & 1,473 & 3,875 & 61,022 & 1,473 & 3,875 & 61,022 & 2,667 & 7,019 & 51,716 \\
\hline 7 & 1,175 & 3,092 & 64,114 & 1,175 & 3,092 & 64,114 & 2,521 & 6,634 & 58,350 \\
\hline 8 & 1,110 & 2,920 & 67,034 & 1,110 & 2,920 & 67,034 & 2,417 & 6,360 & 64,710 \\
\hline 9 & 1,005 & 2,646 & 69,680 & 1,005 & 2,646 & 69,680 & 1,889 & 4,970 & 69,680 \\
\hline 10 &, 832 & 2,188 & 71,868 & & & & & & \\
\hline 11 & ,811 & 2,133 & 74,001 & & & & & & \\
\hline
\end{tabular}

Çıkarım Metodu: Temel Bileşenler Analizi 
4 değişken analiz kapsamı dışına çıkarıldıktan sonra kalan 38 değişkenle oluşturulan faktör yapısı 9 faktörle toplam varyansın \%69,7'sını açıklamaktadır. Bu faktör yapısı başlangıçta tüm değişkenlerle oluşturulan yapıya göre daha açıklayıcıdır. Aşağıda Varimax döndürme yöntemi kullanılarak elde edilen döndürülmüş bileşenler matrisi verilmiştir. Bu matristen hareketle 9 faktörlü yapının bileşenler tespit edilerek isimlendirilmiştir.

Tablo 10. Döndürülmüş bileşen matrisi

\begin{tabular}{|c|c|c|c|c|c|c|c|c|c|}
\hline \multirow{2}{*}{ Değişken } & \multicolumn{9}{|c|}{ Bileşen (Faktörler) } \\
\hline & 1 & 2 & 3 & 4 & 5 & 6 & 7 & 8 & 9 \\
\hline Sunulan tüm hizmet merkezleri modern donanıma sahiptir. & ,080 & ,811 & ,074 & ,188 & 141 &,- 039 & ,134 & ,124 & ,066 \\
\hline Tüm hizmet merkezlerinin görsel açıdan çekici olması & ,069 & ,800 & ,172 & 047 & ,256 & ,069 &, 157 & , 145 & ,110 \\
\hline $\begin{array}{l}\text { Hizmet merkezlerinin çalışanları temiz ve iyi görünümlü } \\
\text { olması }\end{array}$ & ,194 & ,758 & ,143 & ,171 & 160 & 177 & ,110 & ,161 &,- 003 \\
\hline $\begin{array}{l}\text { Hizmet merkezlerin de çalışanlar verdikleri sözleri } \\
\text { zamanında yerine getirmektedir. }\end{array}$ & 272 & ,566 & ,113 & ,194 & 423 & ,117 & ,264 & 144 & 009 \\
\hline $\begin{array}{l}\text { Hizmet merkezlerinin çalışanları müşterilerinin sorunlarıyla } \\
\text { yakından ve samimi bir şekilde ilgilenmektedir }\end{array}$ & ,294 & ,503 & ,060 & ,208 & ,489 & ,054 & ,227 & ,119 & ,018 \\
\hline $\begin{array}{l}\text { Verilen hizmetler ilk seferde doğru bir şekilde yerine } \\
\text { getirilmektedir. }\end{array}$ & ,054 & ,259 & ,103 & ,213 & ,779 & ,166 & ,054 & ,038 & ,049 \\
\hline $\begin{array}{l}\text { Verilen hizmetler söz verildiği zamanda yerine } \\
\text { getirilmektedir }\end{array}$ & ,204 & ,218 & ,218 & ,219 & ,711 & ,080 & ,072 & ,097 & ,066 \\
\hline $\begin{array}{l}\text { Hizmet merkezlerinin çalışanları müşterilere sundukları } \\
\text { hizmetleri hızlı bir şekilde yerine getirir. }\end{array}$ & ,211 & ,250 & ,297 &,- 049 & ,691 &, 120 & ,113 &, 111 & ,199 \\
\hline $\begin{array}{l}\text { Hizmet merkezlerinin çalışanları ürün ve hizmetler } \\
\text { konusunda yeterli bilgi ve donanıma sahiptir. }\end{array}$ & ,611 & ,243 & ,056 & ,148 & 203 & ,316 & ,118 & ,271 &,- 061 \\
\hline $\begin{array}{l}\text { Hizmet merkezlerinin çalışanları müşterilerine yardımcı } \\
\text { olmak için her zaman istekli ve gönüllüdür }\end{array}$ & ,675 & ,129 & ,198 & ,153 & ,118 & ,205 &,- 088 & , 104 & ,112 \\
\hline $\begin{array}{l}\text { Hizmetlerde meydana gelen değişiklikleri müşterilerine } \\
\text { zamanında bildirmektedir }\end{array}$ & ,641 &,- 002 & ,139 & ,026 & ,232 & 299 & 149 & 201 & ,037 \\
\hline $\begin{array}{l}\text { Hizmet merkezleri müşterileri için uygun çalışma saatlerine } \\
\text { sahiptir. }\end{array}$ & ,740 & ,160 & ,179 & ,193 & 028 & ,017 & ,163 & ,028 & ,130 \\
\hline $\begin{array}{l}\text { Hizmet merkezlerinin çalışanları müşterilerinin özel istek ve } \\
\text { ihtiyaçlarını anlar. }\end{array}$ & ,655 & ,068 & ,078 & ,150 & ,173 & ,092 & 255 & ,163 & ,241 \\
\hline Müşterilerinin çıkarlarını ön planda tutulur &, 502 &,- 085 &, 113 &, 171 & ,313 & ,068 & 097 & 043 & ,472 \\
\hline $\begin{array}{l}\text { Hizmetler sözleşmede belirtilen tarifeler üzerinden } \\
\text { ücretlendirir }\end{array}$ & ,173 & ,093 & ,176 & ,250 & 144 & ,039 & ,203 & ,253 & ,645 \\
\hline $\begin{array}{l}\text { Hizmet fiyatlarında meydana gelen değişiklikleri } \\
\text { müşterilerine zamanında bildirir. }\end{array}$ & ,202 & 104 &, 121 & 229 & 039 & ,288 &,- 068 & ,071 & ,735 \\
\hline Çağrı/SMS/MMS fiyatları uygundur. & 199 & ,026 & ,192 & ,036 &,- 004 & ,608 & ,228 &, 102 & ,372 \\
\hline Hat fiyatları uygundur. & ,096 &,- 015 & 062 & ,234 & ,127 & ,736 & ,056 & ,224 & ,149 \\
\hline Uygun tarife avantajlarına sahiptir. & 204 & 244 & 215 &, 052 & 079 & ,765 & ,029 &,- 062 & ,056 \\
\hline \begin{tabular}{|l} 
İnternet servis paket fiyatları uygundur. \\
\end{tabular} & ,097 & ,007 & 236 & ,214 & ,194 & ,620 & ,135 & 241 &,- 008 \\
\hline Yurtdışını arama paket fiyatları uygundur. & 036 & 123 &,- 004 & ,101 &, 083 & ,238 &, 041 &, 574 & ,326 \\
\hline Etkileyici reklam tekliflerine sahiptir. & 205 & 203 & ,284 &, 130 &,- 028 &, 114 &, 170 & ,744 & 017 \\
\hline Reklam sayıs1 yeterlidir. & 175 & ,149 & ,345 & ,132 & ,204 &, 122 & 057 & ,696 &, 050 \\
\hline Yaratıcı reklamlara sahiptir. & ,046 & 246 & ,519 & ,255 & ,113 & ,023 & ,061 & ,546 & ,104 \\
\hline Bilgi verici ve aydınlatıcıdır. & ,192 & ,131 & ,709 & ,141 & ,098 &, 152 &, 125 & ,228 &, 090 \\
\hline Açık ve anlaşılırdır. & 223 &, 121 & ,743 &, 151 &, 175 &, 174 &, 052 &, 173 & ,067 \\
\hline Her kesime hitap etmektedir. & 263 &,- 032 & ,594 & ,240 & ,199 & , 198 & , 166 & ,194 &, 012 \\
\hline $\begin{array}{l}\text { Reklamlar tüm müşteri kitlesine hitap edecek kadar } \\
\text { zengindir. }\end{array}$ & ,137 & ,135 & ,626 & 247 & ,206 & ,208 & ,084 & ,108 &, 159 \\
\hline $\begin{array}{l}\text { En son teknolojiyi takip etmekte ve yenilikleri hizmetlerine } \\
\text { yansıtmaktadır. }\end{array}$ & ,228 & ,293 & ,501 & ,268 & ,086 & ,109 & ,303 & ,037 & ,204 \\
\hline Metro, otopark gibi alanlarda çekmektedir. & , 146 &, 033 & ,228 & ,683 & 166 &, 107 & ,200 &, 042 & ,231 \\
\hline
\end{tabular}


Tablo 10 (devamı). Döndürülmüş bileşen matrisi

\begin{tabular}{|c|c|c|c|c|c|c|c|c|c|}
\hline Kesintisiz konuşma sağlamaktadır. & , 165 & ,306 & ,316 & ,588 &,- 017 & 140 &, 122 &,- 038 & ,273 \\
\hline Ses kalitesi iyidir & , 173 & 247 & 147 & ,761 & ,061 &, 111 & ,156 &, 148 &, 030 \\
\hline İnternet hizmeti hızlıdır. & 103 & ,097 & ,166 & ,733 & ,162 & ,154 &, 122 & ,160 & ,194 \\
\hline 4,5G Hizmetinin ses ve görüntü kalitesi iyidir. & 281 & , 156 & , 166 & ,616 & ,238 & ,136 & ,086 & ,245 & ,016 \\
\hline Aile ve akrabalarım tarafindan kullanılıyor olması önemlidir. & , 190 & ,316 & ,206 & ,211 & ,061 & ,133 & ,627 & ,142 & ,039 \\
\hline Arkadaşlarım tarafından kullanılıyor olması önemlidir. & ,139 & ,155 & ,142 & ,092 & ,085 & , 109 & ,840 & ,068 & ,098 \\
\hline İş arkadaşlarım tarafindan kullanılıyor olmas & 102 &, 129 & 057 & ,195 &, 116 & ,074 & ,817 & ,059 & 015 \\
\hline
\end{tabular}

Çıkarım Metodu: Ana Bileşenler Analizi. Rotasyon Metodu: Varimax

Tablo 10'da görülüyor ki; faktör analizi sonucu ortaya çıkan 9 faktörlü yapıdaki değişkenlerin hangi faktörler altında toplandığı varimax döndürme yöntemi ile gösterilmiştir. Yapılan analizlerde ortaya çıkan faktörler şöyle ifade edilebilir.

1. faktör: Hizmet merkezi çalışanlarının tutumu ve hizmet kalitesi

2. faktör: Hizmet merkezlerinin fiziki atmosferi ve çalışanların ilgisi

3. faktör: Reklamların içeriği

4. faktör: İletişim kalitesi

5. faktör: Hizmet sunumunda hızlılık

6. faktör: Tarife ve fiyat

7. faktör: Yakın çevre

8. faktör: Reklamların etkinliği ve yeterliliği

9. faktör: Dürüstlük başl1klar altında toplamak mümkündür.

\section{IV.SONUC VE ÖNERILER}

Akıllı cep telefonu sektöründe faaliyet gösteren markaların hızlı bir değişim ve yoğun bir rekabetin yaşandığı piyasada yaşamlarını sürdürebilmeleri ve pazar paylarını artırabilmeleri için müşterilerini daha iyi anlamalarını zorunlu kılmaktadır. $\mathrm{Bu}$ yüzden cep telefonu operatörleri müşterilerinin memnuniyet düzeylerini artırabilmek için hizmetlerine sürekli olan yenilerini eklemekte ve kendilerini geliştirmektedirler.

Bu çalışmada Kütahya ilinde cep telefonu kullanıcılarının GSM operatörü tercihine etki eden faktörler belirlenmeye çalışılmıştır. Bu amaçla 260 cep telefonu kullanıcısına anket uygulanmış ve hizmet kalitesi, fiyat, reklam, kapsama alanı, akraba ve yakın çevre faktörleri gibi faktörlerin GSM operatörü tercihindeki etkileri araştırılmıştır. Ankete katılanların \%44,2'si kadın, \%55,8'i erkek olup, üç mobil işletmesi içinde Türk Telekom \%26,9, Turkcell \%33,8 ve Vodafone \%39,2 seviyesinden katılım sağlanmıştır.

Cep telefonu kullanıcılarının geneli için GSM operatörü tercihinde etkili faktörler incelendiğinde çok fazla öne çıkmış bir faktör görülmemiştir. Bununla birlikte reklamların, müşteri çıkarlarını önceliklendirme, uygun tarife avantajlarının, açık ve anlaşılırlı̆̆ın, arkadaşları tarafindan tercih ediliyor olma faktörlerinin GSM operatörü tercihinde nispeten öne çıktığı söylenebilir. GSM kullanıcılarının kullanmış oldukları operatörü tercih etme sebepleri içinde kadın ve erkeklerin farklı algıladıkları hizmetler tespit edilmiştir. Buna göre hizmet merkezlerinin modern donanıma sahip olması, görsel açıdan çekici olması, çalışanların verdikleri sözleri zamanında yerine getirmeleri, hizmetleri ilk seferde doğru yapmaları ve internet hizmetinin hızı ile ilgili hizmetleri erkekler kadınlara göre daha fazla önemsemektedirler. Varyans analizi ile mevcut 3 GSM operatörü 
kullanıcılarının aldıkları hizmetlerle ilgili algılarının değişimi araştırılmıştır. 42 hizmet türünün sadece 11 'inde farkl111klar görülmüş, geri kalan 31 hizmet türünde GSM operatörleri arasında önemli bir fark görülmemiştir. Söz konusu 11 hizmet türünün hemen tamamında bir operatörün daha pozitif bir algiya sahip olduğu anlaşılmıştır. Diğer taraftan tüm değişkenler faktör analizine tabi tutulduğunda 9 faktörlü bir yapı oluşmakta ve bu yapı toplam varyansın \%67,42'sini açıklayabilmektedir. 4 değişken analiz kapsamı dışına çıkarıldıktan sonra kalan 38 değişkenle oluşturulan faktör yapısı 9 faktörle toplam varyansın \%69,7'sini açıklamaktadır.

Bundan sonraki yapılacak çalışmalarda GSM operatörlerine bağlılığı etkileyen faktörler ve mobil kullanıcıların numara taşıma nedenlerini belirleme yönünde araştırmalar yapılabilir. $\mathrm{X}, \mathrm{Y}$ ve $\mathrm{Z}$ kuşaklarının cep telefonu ve operatör tercih nedenleri ve farklıkları incelenebilir. Ayrıca bu çalışma Kütahya'da yapılmış olup benzer çalışmaları farklı illerde ve bölgelerde yaparak sonuçların karşılaştırılması faydalı olabilir.

\section{KAYNAKLAR}

[1] M. Akın, "Cep Telefonu Markalarına Yönelik Memnuniyetin Genç Tüketicilerin Marka Sadakatine Etkisi," Ömer Halisdemir Üniversitesi İktisadi ve İdari Bilimler Fakültesi Dergisi, c.10, s.1, ss. 98-110, 2017.

[2] E. Atmaca ve M. Keskin, "GSM Operatörlerine Yönelik Müşteri Memnuniyet Araştırması," Çukurova Üniversitesi İktisadi ve İdari Bilimler Fakültesi Dergisi, c.18, s.1, ss. 45-63, 2014.

[3] K. Aydın, "Üniversite Öğrencilerinin Cep Telefonu Kullanımı ve Gsm Opreratörü Tercihleri Üzerine Bir Çalışma," Süleyman Demirel Üniversitesi İktisadi ve İdari Bilimler Fakültesi Dergisi, c.9, s1, ss. 149-164, 2004.

[4] S. Barutçu, "GSM Sektöründe Müşteri Bağl1lığı (Pamukkale Üniversitesi Öğrencilerinin GSM Operatörlerine Bağlılıkları Ve Bağl1lıklarını Etkileyen Faktörler)," Afyon Kocatepe Üniversitesi Iktisadi Ve İdari Bilimler Fakültesi Dergisi, c.9, s.1, ss. 349-372, 2007.

[5] H. Bektaş ve M. Aydın, "Measuring Customer Commitment: A case Study From Mobile Phone Market," Atatürk Üniversitesi Iktisadi ve İdari Bilimler Dergisi, c.32, s. 3, ss. 773-791, 2018.

[6] H. Çalıpınar ve M. Soysal, "Kalite Fonksiyon Yayılımı Yönteminin Gsm Operatöründe Uygulanmas1," Hacettepe Üniversitesi İktisadi ve İdari Bilimler Fakültesi Dergisi, c.28, s.2, ss. 95$115,2010$.

[7] M. Değerli, E., Demirbaş ve M. Tolon, "Mobil İşletim Sistemleri (İos Ve Android) Açısından Kullanıcı Memnuniyetini Etkileyen Faktörler," Turkish National Software Engineering Symposium (UYMS 2015): pp.770-781, 2015.

[8] Y. Durmaz ve G. Şerbetçi, "Üniversite Öğrencilerinin Cep Telefonu Tercihlerini Etkileyen Faktörler Ve Bir Uygulama," Akademik Araştırmalar ve Çalışmalar Dergisi (AKAD), c.8, s.14, ss.109-136, 2016. 
[9] R. Doğan, M. Yavuz, İ. Küçükdemirci ve T. Eren, "Öğrencilerde Akıllı Telefon Kullanımının Özellikleri Bakımından Oyun Teorisi İle Analiz Edilmesi," Aksaray Üniversitesi İktisadi ve İdari Bilimler Fakültesi Dergisi, c.7, s.2, ss.67-76, 2015.

[10] S., Doğru ve S. Koçer, "GSM Operatörü Kullanıcılarının Marka Sadakati Üzerine Bir İnceleme” Global Media Journal: Turkish Edition, c.6, s.12, ss.131-171, 2016.

[11] S. Dündar ve F. Ecer, "Öğrencilerin GSM Operatörü Tercihinin, Analitik Hiyerarşi Süreci Yöntemiyle Belirlenmesi," Yönetim ve Ekonomi: Celal Bayar Üniversitesi İktisadi ve İdari Bilimler Fakültesi Dergisi, 15(1): 195-205. 2008.

[12] K. Erkovan, "Akıllı cep telefonları kullanım örüntüleri: Üsküdar örneği”, Yüksek Lisans Tezi, Selçuk Üniversitesi, Sosyal Bilimler Enstitüsü, Konya, 2015.

[13] G., Ekren ve M. Kesim, "Mobil İletişim Teknolojilerindeki Gelişmeler Ve Mobil Öğrenme," Açıköğretim Uygulamaları ve Araştırmaları Dergisi, c.2, s.1, ss. 36-51, 2016.

[14] H. S. Fettahlığlu, "Marka Kişiliği, Marka Sadakati İlişkisi: Akıllı Telefon Kullanıcıları Örneği," Akademik Sosyal Araştırmalar Dergisi, c. 3, s. 9, ss. 210-227, 2015.

[15] S. K. Geyik, "Üniversite Öğrencilerinin İnternet Servis Sağlayıcı Tercihlerini Etkileyen Faktörler Üzerine Bir Araştırma," Ekonometri ve İstatistik e-Dergisi, c.22, s.1, ss. 14-35, 2015.

[16] M. Gülmez, "Üniversite Öğrencilerinin Cep Telefonu Satın Alma Ve Kullanımını Etkileyen Faktörler: Sivas Cumhuriyet Üniversitesi İle Tokat Gaziosmanpaşa Üniversitelerinde Bir Uygulama,” Erciyes Üniversitesi İktisadi ve İdari Bilimler Fakültesi Dergisi, c.24, s.1, ss.37-62, 2005.

[17] A. İnam, “Teknoloji Benim Neyim Oluyor?” Alamuk Yayınları, Ankara, 1993.

[18] S., Kalyoncuoğlu ve E. Faiz, "Akıllı Telefon Pazarı İçin Müşteri Sadakatinin Oluşturulmasında Memnuniyetin, Algılanan Değerin Ve Değiştirme Maliyetinin Etkisi," Third Sector Social Economic Review, c.52, s. 1, ss. 128-147, 2017a.

[19] S., Kalyoncuoğlu ve E. Faiz, "Müşterilerin Sadakat Geliştirme Eğilimlerini Etkileyen Faktörlerin Belirlenmesi: Akıllı Telefon Kullanıcıları Üzerinde Bir Araştırma," Íktisadi ve İdari Bilimler Fakültesi Dergisi, c.19, s. 1, ss.184-210, 2017 b.

[20] Y. Karagöz, K. Çatı, C. M. Koçoğlu, "Cep Telefonu Ve Operatör Tercihinde Etkili Olabilecek Faktörlerin Demografik Özelliklere Bağlı Olarak İrdelenmesi,” Dumlupınar Üniversitesi Sosyal Bilimler Dergisi, c.23, s.1, ss. 1-14, 2015.

[21] S. Karakaş, "Cep Telefonu Pazarında Müşteri Sadakatinin Yapısal Eşitlik Modellemesi İle İncelenmesi," Sosyal Bilimler Dergisi, c.1, s.2012, ss. 1-23, 2012.

[22] M., Korkmaz, A. S. Yücel, A. Aytaç ve S. Gümüş, "GSM Kurum Çalışanlarının Sunduğu Hizmet Kalitesinin Müşteri Memnuniyeti Üzerindeki Etkisinin İncelenmesi," Uluslararası Hakemli Pazarlama Ve Pazar Araştırmaları Dergisi, c.2, s. 4, ss. 63-91, 2015. 
[23] E. Kuşku-Özdemir ve E. B. Güzeloğlu, "Akıllı Telefonlar Ve Marka Değeri Algıları: Üniversite Öğrencileri Üzerine Bir Araştırma," Journal of International Social Research, c.8, s. 40, ss.730-742, 2015.

[24] M. Marangoz, “Ağızdan Ağıza İletişimin Müşterilerin Satın Alma Davranışlarına Etkileri: Cep Telefonu Pazarına Yönelik Bir Araştırma," Journal of The Cukurova University Institute of Social Sciences, c.16, s. 2, ss.395-412, 2007.

[25] S. Nasır, “Türkiye'de GSM Sektöründe Müşteri Memnuniyeti: Kullanıcıların Operatör Değiştirme Eğilimlerinin Saptanması,” 8. Ulusal Pazarlama Kongresi, ss.211-228, 2003.

[26] B. Y. Obeidat, A. B. Abdallah, N. O. Aqqad, A. H. O. M. Akhoershiedah ve M. Maqableh, "The Effect Of İntellectual Capital On Organizational Performance: The Mediating Role Of Knowledge Sharing," Communications and Network, c.9, ss. 1-27, 2017.

[27] I.-E. Ogba ve Z. Tan, "Exploring The İmpact Of Brand İmage On Customer Loyalty And Commitment in China," Journal of Technology Management in China, c.4, s. 2, ss. 132-144, 2009.

[28] G. Özer ve S. Aydın, "GSM Sektöründe Müşteri Sadakati, Memnuniyeti, Değiştirme Maliyeti Ve Güven Arasındaki İlişki," Atatürk Üniversitesi İktisadi ve İdari Bilimler Dergisi, c. 18, s. 3-4, ss. 157-179, 2004.

[29] Ç., Samsa ve L. Gelibolu, "İlişkisel Pazarlamanın İlişki Kalitesi Üzerindeki Etkileri: Kars İli Cep Telefonu Kullanıcıları Üzerinde Bir Araşıırma," Karabük Üniversitesi Sosyal Bilimler Enstitüsü Dergisi, c.5, s.2, ss. 285-299, 2015.

[30] H. Şamkar, “Akıllı Telefon Kullanıcılarının Memnuniyet Düzeylerinde Etkili Olan Faktörlerin İncelenmesi: Eskişehir Örneği” Alphanumeric journal, c.5, s. 1, ss. 147-162, 2017.

[31] E. Şenbabaoğlu, A. Bas, E. S. Dölarslan, "Müşteri Odaklılık Ve Algılanan Kalitenin Müşteri Sadakati Oluşumuna Etkisi," Tüketici ve Tüketim Araştırmaları Dergisi, c. 8, s. 2, ss. 95-124, 2016.

[32] N. Taner, "The Users'evaluations About The Smartphones: An Application At Kastamonu City Centre," Business \& Management Studies: An International Journal, c. 1, s. 2, ss. 127-140, 2014.

[33] M. Türk, H. Binbaşığlu ve M. Deste, "GSM Operatörlerinin Sunmuş Olduğu Gençlik Kampanyalarından Gençlerin Beklentilerine Ve Memnuniyetlerine Yönelik Bir Araştırma,” Eurasian Business \& Economics Journal, c.2, ss. 284-296, 2016.

[34] G. Ö. Türker ve A. Türker, "GSM Operatörleri Sektöründe Marka Sadakatini Etkileyen Faktörlerin Belirlenmesi; Üniversite Öğrencileri Üzerine Bir Uygulama, Electronic Journal of Vocational Colleges, c.3, s1, ss. 49-67, 2013.

[35] E. Uzgören, M. Şengür ve Ü.Yiğit, "Üniversite Öğrencilerinin Cep Telefonu Talebinde İsrafa Yönelik Davranışlarının Analizi Dumlupınar Üniversitesi Öğrencilerine Yönelik Bir Uygulama,” Süleyman Demirel Üniversitesi İktisadi ve İdari Bilimler Fakültesi Dergisi, c.18, s. 1, ss. 29-44, 2013. 
[36] E. Uzgören, M. Şengür ve Ü. Yiğit, "Üniversite Öğrencilerinin Cep Telefonu Talebini Etkileyen Faktörler Dumlupınar Üniversitesi Öğrencilerine Yönelik Uygulama," Afyon Kocatepe Üniversitesi İktisadi Ve İdari Bilimler Fakültesi Dergisi, c.14, s.1, ss.55-72, 2015.

[37] T. Uzunkaya, "Marka Sadakatinin Tekrar Satın Alma Niyetine Etkisi ve Gsm Sektöründe Bir Araştırma," Beykent Üniversitesi Sosyal Bilimler Dergisi, c.9, s. 2, ss. 58-67, 2016.

[38] F. Zanco, "GSM operatörü tercihinde etkili olan nedenlerin önem düzeylerini belirlemeye yönelik bir analiz," Yüksek Lisans Tezi, Gümüşhane Üniversitesi, Sosyal Bilimler Enstitüsü, Gümüşhane, 2015.

[39] A. M. Zengin, "Doğrudan Pazarlama Aracı Olarak Cep Telefonu Kullanımı Ve Tüketici Tutumları” Yüksek Lisans Tezi, Selçuk Üniversitesi, Sosyal Bilimler Enstitüsü, Konya, 2010. 